Jurnal Konstruksi Hukum | ISSN: XXXX | E-ISSN: XXXX Vol. 1, No. 1, September 2020 Hal. 78-83| Available online at https://www.ejournal.warmadewa.ac.id/index.php/jukonhum DOI: https://doi.org/10.22225/jkh.1.1.2134.78-83

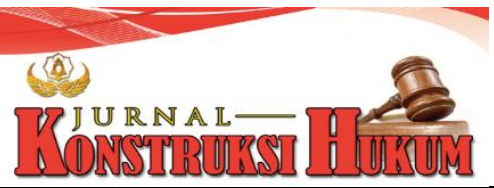

\title{
PENERAPAN PERATURAN DAERAH KOTA DENPASAR NOMOR 3 TAHUN 2015 TENTANG PENGELOLAAN SAMPAH
}

\author{
Dewa Gede Agus Anjaswara, I Gusti Bagus Suryawan, Luh Putu Suryani \\ Fakultas Hukum Universitas Warmadewa, Denpasar-Bali, Indonesia
}

\begin{abstract}
Abstrak
Kota Denpasar belum mampu melakukan pengelolaan sampah dengan baik, padahal pengelolaan sampah sangat penting untuk mengurangi volume sampah, bahkan dapat memanfaatkan sampah menjadi benda atau produk yang bermanfaat. Kota Denpasar berupaya mengelola sampah di Denpasar. Tujuan penelitian ini yaitu untuk mengetaui bagaimana implementasi Peraturan Kota Denpasar Nomor 3 Tahun 2015 tentang Pengelolaan Sampah dan mengetahui faktor pendukung dan penghambat berlakunya Peraturan Pemerintah Kota Denpasar Nomor 3 Tahun 2015 tentang Pengelolaan Sampah. Penelitian ini didesain dengan menggunakan penelitian hukum empiris dengan pendekatan statutory. Teknik pengumpulan data yang digunakan dalam penelitian adalah wawancara dan dokumentasi. Hasil penelitian menunjukan bahwa tindakan pemerintah kota denpasar terhadap pelanggaran Peraturan Daerah Kota Denpasar Nomor 3 Tahun 2015 tentang pengelolaan sampah adalah menerapkan tindak pidana ringan terhadap pelanggar dimana yang melanggar diadili di pengadilan pidana ringan (Tipiring). Kemudian, faktor pendukung dan penghambat penegakan Peraturan Daerah Nomor 3 Tahun 2015 tentang Pengelolaan Sampah merupakan landasan hukum pengelolaan kebersihan yang telah dikeluarkan oleh Pemerintah Kota Denpasar baik berupa Peraturan Perundang-undangan, Peraturan Daerah, dan Walikota Denpasar. Faktor penghambat penegakan Sanksi Peraturan Daerah Nomor 3 Tahun 2015 tentang Pengelolaan Sampah, yaitu faktor aparat penegak hukum, faktor sarana dan prasarana, dan faktor masyarakat.
\end{abstract}

Kata Kunci: Pengelolaan sampah; Penerapan Perda Kota Denpasar

\begin{abstract}
The city of Denpasar has not been able to carry out waste management properly, even though waste management is very important to reduce the volume of waste, and it can even use waste into useful objects or products. Denpasar City tries to manage waste in Denpasar. The purpose of this research is to find out how the implementation of Denpasar City Regulation Number 3 of 2015 concerning Waste Management and to find out the supporting and inhibiting factors of the enactment of Denpasar City Government Regulation Number 3 of 2015 concerning Waste Management. This study was designed using empirical legal research with a statutory approach. The data collection techniques used in the study were interviews and documentation. The results show that the action of the Denpasar city government against violations of the Regional Regulation of the City of Denpasar Number 3 of 2015 concerning waste management is to implement minor crimes against offenders where those who violate are tried in light criminal court (Tipiring). Then, the supporting and inhibiting factors for the enforcement of Regional Regulation Number 3 of 2015 on Waste Management are the legal basis for cleanliness management that has been issued by the Denpasar City Government in the form of Legislation, Regional Regulations, and the Mayor of Denpasar. Inhibiting factors for the enforcement of Sanctions by Regional Regulation No.3 of 2015 on Waste Management, namely factors of law enforcement officers, facilities and infrastructure factors, and community factors.
\end{abstract}

Keywords: Waste management; Implementation of Denpasar regulation

\section{PENDAHULUAN}

Kota Denpasar sebagai pusat pemerintahan sampai saat ini belum dapat melakukan pengelolaan sampah secara baik. Pengelolaan sampah bertujuan untuk menekan volume sampah serta memanfaatkan sampah menjadi produk yang bermanfaat. Pengelolaan sampah yang dilakukan, dalam hal ini Dinas Kebersihan dan Pertamanan Kota Denpasar memerlukan depo pengolahan sampah. Untuk itu Kota Denpasar berusaha untuk mengelola sampah di Denpasar. Sampah-sampah sebelum masuk Tempat Pembuangan Akhir (TPA), terlebih dahulu masuk ke depo, kemudian dari depo sampah tersebut dipilah. Sampah yang masih berguna langsung didaur ulang. Selain banyaknya sampah plastik, terdapat juga sampah bekas upacara keagamaan maupun sampah dari tradisional. Penumpukan sampah berdampak terhadap tanah yang tercemar. Sampah yang dibakar menyebabkan 
udara tercemar. Sampah dibuang ke sungai/selokan berdampak terhadap air. Banyaknya pencemaran terhadap sampah yang dilakukan oleh masyarakat berdampak terhadap lingkungan di Kota Denpasar.

Sampah adalah masalah sosial yang harus mendapatkan perhatian dari berbagai pihak. Sampah pasti akan diproduksi oleh semua orang. Sampah yang tertimbun secara terus menerus, yang tidak bisa menyebabkan timbulnya permasalahan (Sucipto, 2012). Penanganan sampah yang tidak bijaksana berdampak langsung terhadap penularan berbagai macam penyakit kulit dan gangguan pernafasan. Sedangkan akibat tidak langsung penanganan sampah yang tidak bijaksana adalah bahaya banjir karena tersumbatnya aliran air di sungai. Polusi sampah menurut ahli kesehatan, menyebabkan dampak buruk yaitu terhadap kesehatan. Pihak berwenang dalam hal ini pemerintah berwenang menegakkan hukum supaya norma yang telah di buat tersebut dipatuhi oleh setiap orang. Pemerintah berwenang menegakan hukum lingkungan melalui. Pengawasan dan penerapan sanksi hukum. Pengawasan yang dilakukan berupa penetapan peraturan perundang-undangan di bidang lingkungan hidup. Berdasarkan latarbelakang masalah tersebut di atas, maka penelitian baru ini bertujuan untuk mengetahui penerapan Peraturan Daerah Kota Denpasar Nomor 3 Tahun 2015 tentang Pengelolaan Sampah dan untuk mengetahui faktor pendukung dan penghambat penegakan sanksi Peraturan Daerah Kota Denpasar Nomor 3 Tahun 2015 tentang Pengelolaan Sampah.

Beberapa penelitian terkait dengan pengelolaan sampah telah banyak dilakukan oleh peneliti sebelumnya seperti Amir \& Anto (2018); Elele \& Subanda (2020); McAllister (2015); Pertiwi, Winaya, Andayani, \& Kristinayanti (2019) mengatakan bahwa pengelolaan persampahan merupakan isu multidimensi yang mencakup aspek politik, kelembagaan, sosial, lingkungan, dan ekonomi. Meningkatkan pengelolaan sampah berkelanjutan di negara berkembang membutuhkan upaya untuk meningkatkan kesadaran publik, meningkatkan pendanaan, membangun keahlian, dan berinvestasi dalam infrastruktur. Untuk membuat kemajuan, masyarakat perlu merangkul sistem baru pengelolaan sampah berkelanjutan yang partisipatif, terintegrasi secara kontekstual, kompleks, dan adaptif. Kemudian, Matsumoto, (2020); Munguía-López, Zavala, Santibañez-Aguilar, \& Ponce-Ortega (2020); Putra, Surata, \& Agung (2017); Rigamonti et al., (2020) mengatakan bahwa Pengelolaan sampah kota (MSW) merupakan masalah logistik yang penting namun kompleks oleh karena itu perlu kerangka koordinasi dalam menangani sampah.

Berdasarkan uraian masalah di atas, maka penelitian yang baru ini bertujuan untuk mengetaui bagaimana implementasi Peraturan Kota Denpasar Nomor 3 Tahun 2015 tentang Pengelolaan Sampah dan mengetahui faktor pendukung dan penghambat berlakunya Peraturan Pemerintah Kota Denpasar Nomor 3 Tahun 2015 tentang Pengelolaan Sampah.

\section{METODE PENELITIAN}

Penelitian ini didesain dengan menggunakan penelitian hukum empiris. Penelitian hukum empiris adalah suatu metode dengan menggunakan fakta- fakta empiris yang diambil dari perilaku manusia dengan wawancara dan pengamatan langsung (Arikunto, 2002). Sumber data dalam penelitian ini adalah data primer dan sekunder. Data primer adalah data dari lapangan yang diperoleh secara langsung. Teknik pengumpulan data yang dipergunakan dalam penelitian ini adalah wawancara dan dokumentasi. Data tersebut kemudian dianalisis secara kualitatif dan disajikan dengan cara deskriptif.

\section{HASIL DAN PEMBAHASAN}

Pelaksanaan Perda Kota Denpasar Nomor 3 Tahun 2015 Tentang Pengelolaan Sampah yang dituangkan dalam pasal 40. Penerapan pelaksanaan Peraturan Daerah Kota Denpasar Nomor 3 Tahun 2015 dilakukan oleh Walikota dibantu pejabat fungsional di bidang pengelolaan sampah yakni Dinas Kebersihan dan Pertamanan Kota Denpasar. Instansi yang bertanggung jawab terhadap pengelolaan sampah adalah:

1. Dinas kebersihan dan Pertamanan bertugas melaksanakan urusan pemerintahan daerah di bidang kebersihan dan pertamanan.

2. Kantor Lingkungan Hidup bertugas menyusun dan melaksanakan kebijakan daerah di bidang lingkungan hidup.

3. Satuan Polisi Pamong Praja bertugas memelihara dan menyelenggarakan ketentraman serta ketertiban umum.

4. Kecamatan bertugas melakukan kewenangan pemerintahan yang dilimpahkan oleh Bupati untuk menangani sebagian urusan otonomi daerah. 
5. Kelurahan bertugas menyelenggarakan urusan pemerintahan, pembangunan dan kemasyarakatan.

Pelaksanaan Perda Tentang Pengelolaan Sampah penulis melakukan wawancara dengan Bapak I Ketut Wisada selaku Kepala Dinas Kebersihan dan Pertamanan Kota Denpasar pada tanggal 12 Januari 2020, mengatakan bahwa Perda Tentang Pengelolaan Sampah masih belum dapat dilaksanakan secara maksimal, hal ini karena masih banyaknya terjadi pelanggaran yang dilakukan oleh warga masyarakat kota Denpasar. Pelanggaran yang dilakukan tersebut seperti membuang sampah secara sembarangan dan sampah yang dibuang tidak sesuai dengan jadwal yang telah ditetapkan. Permasalahan pembuangan sampah sampai saat ini semakin bermunculan. Sampah yang menggunung dan dibuang sembarangan di tempat-tempat yang bukan semestinya, seperti sampah yang ditemukan di pinggir -pinggir jalan maupun sampah yang dibuang seenaknya di sungai. Masyarakat kurang menyadari akan pentingnya kebersihan lingkungan. Perilaku masyarakat seperti ini menunjukan Perda Kota Denpasar tidak dapat berjalan dengan baik. Pemerintah sebagai penegak hukum dan masyarakat tidak bisa bekerjasama dalam melaksanakan peraturan tersebut.

Pengelolaan sampah berkaitan dengan keberadaan Perda Nomor 3 Tahun 2015 masalah yang dihadapi pemerintah adalah sedikitnya sosialisasi kepada masyarakat tentang Perda tersebut. Dinas Kebersihan dan Pertamanan Cuma bisa memberikan himbauan dan penyuluhan tetapi tidak dapat memberikan sanksi yang tegas terhadap pelanggar. Jika terjadi pelanggaran terhadap peraturan yang telah ditetapkan maka diberlakukan sanksi denda/ kurungan dan sanksi moril/sosial agar bisa Perda Kota Denpasar Nomor 3 Tahun 2015 dilaksanakan dengan semaksimal mungkin, sehingga pembuangan sampah yang dilakukan oleh masyarakat dapat diatasi dan masyarakat sudah memahami akan pentingnya menjaga lingkungan dari sampah.

Salah satu upaya pemerintah Kota Denpasar menangani masalah adalah Perda Kota Denpasar Nomor 3 tahun 2015 mengenai Seruan No 658.5/2114/DKP. Untuk menciptakan kota Denpasar "BERSERI" (Bersih, Sehat, Rindang, dan Indah) yang berwawasan budaya, maka berdasarkan Perda tentang Pengelolaan Sampah ditetapkan peraturan kepada segenap lapisan masyarakat berdasarkan Pasal 34, dimana dalam Pasal ini diatu $r$ mengenai larangan yang harus ditaati oleh setiap orang dikota Denpasar. Bentuk pelaksanaan Perda Tentang Pengelolaan Sampah ini adalah dengan menangkap para pelanggar, dalam hal ini adalah masyarakat yang membuang sampah sembarangan. Pihak Dinas Lingkungan Hidup dan Kebersihan melalui kelompok Satuan Tugas (SATGAS) memiliki tugas untuk menangkap masyarakat yang secara sengaja membuang sampah tidak pada tempatnya, seperti di tanah kosong, sungai, jalan raya, dan lain-lain. Setelah itu sanksi pidana yang dijatuhkan kepada para pelanggar adalah berupa denda atau pidana kurungan.

Peraturan tersebut cukup efektif untuk mengurangi masalah sampah yang berserakan di jalan karena waktu buang sampah telah diatur. Tetapi yang tak kalah penting adalah bagaimana penge lolaan sampah di TPA (Tempat Pembuangan Akhir). Karena akan memunculkan permasalahan baru pada lingkungan di sekitar TPA baik pencemaran terhadap Tanah, air dan udara. Masalah sampah bukan hanya menjadi tanggung jawab pemerintah saja, tetapi tanggung jawab semua pihak. Sehingga dapat menciptakan kota yang indah, asri dan terbebas dari sampah. Hasil berdasarkan wawancara penulis dengan Ida Bagus Putra Wirabawa pada tanggal 11 Januari 2020, mengatakan pemerintah belum efektif dalam pengambilan tindakan dan pemberian sanksi kepada masyarakat yang melanggar serta hambatan yang sangat berpengaruh ialah belum adanya peraturan mengenai penerapan atau sanksi yang harus dilaksanakan.

Tindakan Pidana Tipiring yang diberlakukan oleh Pemerintah Kota Denpasar telah diterapkan terhadap pelanggar yang disidangkan. Pemerintah Kota Denpasar, Dinas Satuan Polisi Pamong Praja (Satpol PP) berwenang menerapkan sanksi administrasi. Satgas Dinas Keamanan dan Pertamanan dibentuk untuk mengawasi pelanggaran-pelanggaran yang terjadi dan mengupayakan penambahan beberapa fasilitas angkutan sampah serta menambah personil untuk mengangkut sampah dari TPS menuju TPA. Pemaksimalan kinerja di lapangan memerlukan peran aktif dari masyarakat dalam penanganan masalah sampah.

Tindakan pidana ringan berupa pembinaan untuk memberikan efek jera kepada pelanggar. Upaya ini dilakukan secara terus menerus tanpa mengenal waktu maupun tempat. Masyarakat yang mengalami kesulitan dalam membuang sampah disarankan untuk membentuk kelompok pengelolaan sampah yang bersifat swakelola. Pembentukan kelompok tersebut membuktikan masyarakat sudah mulai mewujudkan kebersihan secara langsung. Peran serta masyarakat Kota Denpasar dalam 
menjaga kebersihan lingkungan sangatlah diperlukan oleh Dinas Kebersihan dan Pertamanan untuk mengatasi kebersihan di Kota Denpasar.

Pengelolaan kebersihan yang telah diterbitkan oleh Pemerintah Kota Denpasar baik dalam bentuk Undang-Undang, Perda, maupun Perwali Denpasar merupakan faktor pendukung penegakan sanksi Peraturan Daerah Nomor 3 Tahun 2015 adalah sebagai berikut.

1. Undang-Undang No. 18 Tahun 2008 yang mengatur tentang pengolahan dan penanganan sampah. UU tersebut menjadi salah satu upaya pemerintah Indonesia untuk mengatasi masalah sampah yang ada. Menurut peraturan tersebut apa bila membuang sampah di saluran air atau sungai akan diancam pidana 6 tahun atau denda Rp. 100.000.000. peraturan tersebut temuat dalam Perda Nomor 5 Tahun 2013 Pasal 46.

2. Peraturan Daerah Provinsi Bali Nomor 5 Tahun 2011 tentang Pengelolaan Sampah Dalam perda ini disebutkan bahwa setiap orang yang melanggar dapat diancam dengan pidana kurungan paling lama 6 bulan atau denda sebanyak lima puluh juta rupiah.

3. Perda Nomor 3 Tahun 2015 tentang Pengelolaan Sampah Jadwal pembuangan sampah ditetapkan dari sore pukul 17.00 Wita sampai pukul 19.00 Wita pada tempat yang telah disediakan. Pemberitahuan ini telah terpampang pada papan pengumuman di beberapa titik tempat pembuangan sampah.

4. Perda Nomor 3 Tahun 2000 tentang Kebersihan dan Ketertiban Umum

Perda Kota Denpasar Nomor 3 Tahun 2015 berlaku bagi siapa saja yang membuang sampah sembarangan semisal di sungai, tempat umum, dan membuang sampah di jalan maka konsekuensinya dari melanggar larangan yang telah disebutkan tadi akan diancam pidana kurungan selam a-lamanya tiga bulan dan denda paling maksimal Rp 5.000.000. Sedangkan waktu membuang sampah ditentukan dimulai dari pukul 17.00 wita -19.00 wita.

5. Peraturan Daerah Kota Denpasar Nomor 1 Tahun 2015 tentang Ketertiban Umum.

Peraturan ini menjelaskan tentang berbagai bentuk pelanggaran membuang sampah maupun limbah rumah tangga serta menjelaskan denda seperti pelanggaran membuang sampah sembarangan, membuang limbah rumah tangga ke selokan, membiarkan hewan peliharaan merusak, mengotori serta mencemari lingkungan akan diancam dengan kurungan atau dikenakan denda.

6. Perwali Nomor 3 Tahun 2012

Pelanggaran yang dilakukan oleh warga yang membuang sampah pada tidak pada tempatnya atau tidak pada jadwalnya, akan dilakukan penindakan. Pelanggar disidangkan pada persidangan tindak pidana ringan (tipiring). Tak hanya membebankan sanksi administratif kepada masyarakat yang telah mengabaikan aturan pembuangan sampah sesuai dengan Perda. Tindakan pemberian peringatan maupun tindakan hukum berupa sanksi ini, bertujuan untuk memberikan efek jera kepada masyarakat yang kemudian membuat masyarakat lebih sadar dan turut mewujudkan Denpasar bersih dan rindang.

7. Perwali Nomor 35 tahun 2006

Perwali Nomor 35 Tahun 2006, disini Pemerintah Kota Denpasar memberikan kewenangan kepada Desa/Kelurahan, Desa Pekraman, Dusun, Lingkungan, Banjar untuk membentuk Kelompok Swakelola Kebersihan di masing-masing wilayahnya.

8. Perwali No 11 Tahun 2016 mengenai Tata Cara Pengelolaan dan Pembuangan Sampah Di Kota Denpasar

Perwali ini mewajibkan masyarakat untuk membuang sampah secara mandiri ke tempat pembuangan sampah sementara atau ikut program swakelola sampah. Warga yang melanggar Perwali ini dikenakan sanksi denda hingga Rp 50 Juta atau kurungan penjara 3 bulan. Efektivitas dari suatu produk hukum ditentukan oleh beberapa faktor, yaitu faktor aparatur penegak hukum, faktor prasarana dan faktor masyarakat.

\section{a. Faktor Aparatur Penegak Hukum}

Dinas Pertamanan Dan Kebersihan Kota Denpasar merupakan faktor aparatur penegak hukum yang bertanggung jawab terhadap persampahan, seperti pelayanan berupa mengangkut sampah. Pelayanan tersebut diberikan terhadap semua warga masyarakat baik yang tinggal di perumahan maupun yang tinggal bukan di perumahan. Pengawasan yang kurang maksimal mengakibatkan masih banyaknya warga yang membuang sampah ke sungai. 
Penegakan hukum terhadap pelanggaran Perda Nomor 3 Tahun 2015 belum berjalan secara efektif. Hal ini terlihat dari banyaknya warga yang membuang sampah sembarangan. I Ketut Wisada, dalam wawancara tanggal 12 Januari 2020, mengatakan bahwa masih banyak warga kota yang membuang sampahnya ke sungai, disebabkan pengawasan yang lemah. Pengawasan yang lemah terjadi karena untuk mengawasi warga yang membuang sampah sembarangan dibutuhkan banyak tenaga pengawas. Tenaga pengawas yang dimiliki sangat terbatas jumlahnya. Jumlah petugas kebersihan hanya 1.400 orang, untuk mengurusi sampah di 4 kecamatan dan 43 kelurahan di Kota Denpasar sehingga beberapa jalan protokol belum dapat dijangkau oleh petugas kebersihan, karena itu diperlukan adanya pengawasan.

b. Faktor Sarana dan Prasarana

Faktor sarana dan fasilitas dalam hal ini adalah jumlah dari SATGAS yang sangat tidak memadai dengan luas wilayah kota Denpasar. Sampai saat ini SATGAS hanya memiliki 45 (Empat Puluh Lima) anggota. Kekurangan ini menjadi hambatan mengingat luas kota Denpasar yang sangat luas sehingga penegakan hukum dari SATGAS tidak berjalan secara maksimal. Pelayanan yang dilakukan belum maksimal diakibatkan oleh faktor kurangnya sarana dan prasarana. Armada pengangkut sampah masih sangat terbatas, dan armada pengangkut sampah banyak yang rusak serta jumlah petugas dinas kebersihan yang masih sangat kurang.

Menurut wawancara dengan Adi Wiguna pada tanggal 12 Januari 2020 mengemukakan bahwa ketersediaan prasaran a dan sarana pendukung pengelolaan kebersihan masih belum mencukupi jumlahnya dan kualitasnya masih kurang baik. Kondisi layak pakai prasarana dan sarana kebersihan diantaranya sebanyak 9 unit dump truck, 16 unit container, 4 unit mesin rumput gendong, dan 4 unit mesin rumput dorong yang tidak layak pakai.

\section{c. Faktor Masyarakat}

Kesadaran, kepatuhan dan kurangnya pengetahuan dan pemahaman dari masyarakat yang menyebabkan tidak efektifnya suatu peraturan perundang-undangan. Masyarakat kota Denpasar yang belum sadar akan pentingnya kebersihan lingkungan mereka, hal ini terlihat dari banyaknya masyarakat yang masih membuang sampah sembarangan ke sungai atau meletakkan di depan rumah mereka. Ketidaktahuan dari masyarakat akan adanya Peraturan Daerah yang mengatur mengenai sanksi membuang sampah sembarangan dan membuang sampah tidak pada waktunya menyebabkan terjadinya banyak pelanggaran yang diakibatkan oleh ketidaktahuan masyarakat itu sendiri.

Wawancara dengan I Ketut Wisada pada tanggal 12 Januari 2020, mengatakan ada kecenderungan saat ini warga masyarakat membuang sampahnya ke sungai disaat pelarangan pembuangan sampah di jalanan digencarkan. Untuk itulah disamping terus menindak pelanggar sampah di daratan, pemantauan serta penindakan para pelanggar sampah di sungai harus lebih dioptimalkan dan terus dikawal.

Wawancara dengan Ketut Adi Wiguna pada tanggal 12 Januari 2020, mengemukakan sistem pembuangan sampah saat ini belum berjalan tertib. Pembuangan sampah jam 5 sore sampai jam 7 malam yang telah dibuat oleh pemerintah sering tidak dipatuhi. Ketidakpatuhan masyarakat terhadap jadwal-jadwal pembuangan sampah yang telah ditetapkan sehingga peraturan yang dibuat belum terlaksana dengan maksimal.

\section{SIMPULAN DAN SARAN}

\section{Simpulan}

Berdasarkan hasil dan pembahasan di atas, maka dapat disimpulkan bahwa tindakan Pemerintah Kota Denpasar terhadap pelanggaran Perda Nomor 3 Tahun 2015 adalah menerapkan Tindakan Pidana Ringan kepada pelanggar yang disidangkan pada persidangan tindak pidana ringan (tipiring). Penerapan sanksi administrasi dilakukan oleh Dinas Satuan Polisi Pamong Praja yang memiliki kewenangan dalam menindak suatu pelanggaran terhadap lingkungan, menertibkan dan menindak warga masyarakat atau badan hukum yang menggang gu ketentraman dan ketertiban umum. Kemudian, faktor pendukung dan penghambat penegakan sanksi Peraturan Daerah Nomor 3 Tahun 2015 Tentang Pengelolaan Sampah bentuk Undang- Undang, Peraturan Daerah, maupun Peraturan Walikota Denpasar. Faktor penghambat penegakan Sanksi Perda Nomor 3 Tahun 2015 yaitu: 1) faktor aparatur penegak hukum, 2) faktor sarana dan prasarana, dan 3) faktor masyarakat. 


\section{Saran}

Melalui penelitian ini diharapkan kepada pihak Pemerintah Kota Denpasar diharapkan melakukan sosialisasi kepada masyarakat mengenai Peraturan Daerah yang akan diterapkan sehingga masyarakat tahu akan sanksi yang diterima jika melakukan pembuangan sampah sembarangan dan pembuangan sampah tidak tepat pada waktunya. Kemudian, pembuatan perda khususnya mengenai sampah, sebaiknya para anggota Dewan dan Pemerintahan Kota Denpasar mendengarkan aspirasi masyarakat. Agar peraturan tersebut mendapatkan masukan -masukan dari masyarakat dan terjadi komunikasi dua arah antara pemerintah dan masyarakat serta memberikan reward kepada warga yang peduli terhadap masalah sampah dan lingkungan.

\section{DAFTAR PUSTAKA}

Amir, M., \& Anto, R. P. (2018). A Study Policy Implementation of Waste Management in Konawe Regency-Indonesia. Journal of Sustainable Development, 11(1), 90.

Arikunto, S. (2002). Prosedur Penelitian Suatu Pendekatan Praktek. Jakarta: Rineka Cipta.

Elele, E. C., \& Subanda, I. N. (2020). Residents Social Behavior in The Implementation of Denpasar City Waste Management Policy. Jurnal Ilmiah Ilmu Administrasi Publik: Jurnal Pemikiran Dan Penelitian Administrasi Publik, 10(1), 123-132.

Matsumoto, S. (2020). Do individuals free ride on participation in environmental policies? Personal values and waste management practices. Ecological Economics, 174(March), 106669.

McAllister, J. (2015). Factors influencing solid-waste management in the developing world. All Graduate Plan B and Other Reports, 299, 1-95.

Munguía-López, A. del C., Zavala, V. M., Santibañez-Aguilar, J. E., \& Ponce-Ortega, J. M. (2020). Optimization of municipal solid waste management using a coordinated framework. Waste Management, 115, 15-24.

Pertiwi, I. G. A. I. ., Winaya, N. A. ., Andayani, K. W., \& Kristinayanti, W. S. (2019). Waste management system on Badung River area in Bali. IOP Conference Series: Earth and Environmental Science, 351(1), 1-11.

Putra, I. G. N. G., Surata, S. P. K., \& Agung, G. A. A. (2017). Medical waste management strategy in the inpatient primary health care center with system approach: A SWOT Analysis. Bali Medical Journal, 6(3), 33-39.

Rigamonti, L., Taelman, S. E., Huysveld, S., Sfez, S., Ragaert, K., \& Dewulf, J. (2020). A step forward in quantifying the substitutability of secondary materials in waste management life cycle assessment studies. Waste Management, 114, 331-340.

Sucipto, C. D. (2012). Teknologi Pengolahan Daur Ulang Sampah. Jakarta: Gosyen Publishing. Undang-Undang RI Tahun 1945.

Undang-Undang Nomor 18 Tahun 2008 Mengenai Pengelolaan Sampah. Peraturan Daerah Kota Denpasar Nomor 3 Tahun 2015 mengenai Pengelolaan Sampah 